\title{
Pengaruh Penerapan Pembelajaran Kooperatif Tipe Think Talk Write (T'TW) Terhadap Kemampuan Pemecahan Masalah Matematika Ditinjau Dari Kemampuan Awal Matematika
}

\author{
Fahri Riansyah ${ }^{1}$, Arnida Sari² \\ Jurusan Pendidikan Matematika, Universitas Islam Negeri Sultan Syarif Kasim Riau \\ e-mail: fahririansyah@gmail.com arnidasari@uin-suska.ac.id
}

\begin{abstract}
ABSTRAK. Penelitian ini dilatar belakangi oleh rendahnya kemampuan pemecahan masalah matematika siswa di MTsN Danau Bingkuang. Penelitian ini bertujuan untuk menyelidiki ada tidaknya perbedaan kemampuaan pemecahan masalah matematika antara siswa yang mengikuti pembelajaran Think Talk Write dengan siswa yang mengikuti pembelajaran langsung yang ditinjau dari kemampuan awal siswa MTs Negeri Danau Bingkuang. Yang mana menyelidiki dengan cara memberikan perlakuan pada salah satu kelas dan membandingkan hasilnya dengan salah satu kelas yang diberikan perlakuan yang berbeda. Subjek dalam penelitian ini adalah siswa kelas VII.1 dan kelas VII.2 MTs Negeri Danau Bingkuang. Teknik analisis data yang digunakan peneliti yaitu uji-t dan anova dua arah (two way $A N O V A$ ). Instrumen yang digunakan adalah tes uraian untuk mengukur kemampuan pemecahan masalah matematika siswa dan mengukur kemampuan awal siswa. Berdasarkan hasil penelitian disimpulkan bahwa; (1) Terdapat perbedaan kemampuan pemecahan masalah matematika antara siswa menggunakan model pembelajaran Think Talk Write dengan siswa menggunakan model pembelajaran langsung, (2) Terdapat perbedaan kemampuan pemecahan masalah matematika antara siswa yang belajar menggunakan model pembelajaran kooperatif tipe TTW dengan siswa yang belajar menggunakan pembelajaran langsung jika ditinjau dari kemampuan awal siswa, dan (3) Tidak terdapat interaksi antara model pembelajaran dan kemampuan awal siswa terhadap kemampuan pemecahan masalah siswa. Dengan demikian secara model pembelajaran Think Talk Write berpengaruh terhadap kemampuan pemecahan masalah matematika yang ditinjau dari kemampuan awal siswa MTs N Danau Bingkuang.
\end{abstract}

Kata Kunci: Model Think Talk Write, Kemampuan Pemecahan Masalah Matematika, Kemampuan Awal Matematika

\section{PENDAHULUAN}

Matematika merupakan suatu ilmu dasar dalam kehidupan manusia yang mempunyai peranan penting dalam mendorong perkembangan ilmu-ilmu lain serta mampu dalam upaya penguasaan ilmu pengetahuan dan teknologi di dunia yang semakin berkembang. Dapat dikatakan bahwa perkembangan pesat pada bidang teknologi, informasi dan komunikasi dilandasi oleh perkembangan matematika. Penguasaan matematika yang kuat sejak dini diperlukan siswa untuk menguasai dan menciptakan suatu teknologi pada masa mendatang. Oleh karena itu dalam upaya meningkatkan mutu pelajaran matematika, tenaga kependidikan dituntut selalu meningkatkan diri dalam ilmu pengetahuan matematika.

Menurut Cockrof, "Matematika sangat dibutuhkan dan berguna dalam pernyataan Suherman dan Wina Putra yang menyatakan : "Matematika sebagai ratu atau ibunya ilmu dimaksudkan bahwa matematika adalah sebagai sumber dari ilmu yang lain. Dengan perkataan lain, banyak ilmu-ilmu yang penemuan dan pengembangannya bergantung dari matematika"(Suhermen, et.al, 1999). 
Salah satu tujuan pembelajaran matematika menurut Permendiknas Nomor 22 Tahun 2006 adalah memahami konsep matematika, menjelaskan keterkaitan antar konsep dan mengaplikasikan konsep atau algoritma secara luwes, akurat, efisien, dan tepat dalam pemecahan masalah (Depdiknas, 2006). Berkaitan dengan tujuan tersebut kemampuan pemecahan masalah dalam matematika sangat diperlukan bagi siswa, karena ketika siswa sudah bisa paham dengan kemampuan pemecahan masalah matematika yang ada maka siswa akan lebih mudah dalam menyelesaikan sebuah permasalahan dan bisa membentuk siswa yang kreatif dan kritis.

Pentingnya kemampuan pemecahan masalah ini juga ditunjukkan dari hasil Program for International Assesment of Student (PISA) pada tahun 2012 menyatakan skor rata-rata siswa dalam pembelajaran matematika adalah 375 dan mendapatkan peringkat ke-64 dari 65 peserta, sedangkan pada tahun 2015 Indonesia menduduki peringkat ke-69 dari 76 negara. Hasil TIMSS pada tahun 2011 menyatakan skor rata-rata matematika siswa adalah 386 dan mendapatkan peringkat ke-41 dari 45 peserta, sedangkan pada tahun 2015 Indonesia berada pada ranking ke-36 dari 49 negara. Berdasarkan hasil TIMSS yang diperoleh menunjukkan bahwa kemampuan matematika siswa Indonesia masih jauh di bawah median internasional yang berada pada nilai 500, level tinggi hanya dicapai $2 \%$, sedangkan level menengah 15\%, dan secara kumulatif kemampuan matematika siswa Indonesia mencapai level rendah yaitu 43\% siswa kelas VIII. Dimensi penilaian pada TIMSS meliputi dimensi konten dan dimensi kognitif yang masing-masing terdiri dari tiga domain yaitu mengetahui fakta dan prosedur (pengetahuan), menggunakan konsep, penerapan dan pemecahan masalah (Rizki Herlina Wati Putri, 2017). Salah satunya hasil dari penelitian yang dilakukan Suraji (2018) di SMP pada Pekanbaru menganalisis bahwa terdapat permasalahan kemampuan pemecahan masalah matematis siswa.

Berdasarkan hasil observasi peneliti dengan guru matematika MTs Negeri Danau Bingkuang terhadap hasil belajar siswa, terutama pada aspek pemecahan masalah matematika, terdapat gejala-gejala sebagai berikut: 1) Ketika diberikan soal yang berbeda dengan yang dijelaskan oleh guru banyak dari siswa yang kurang percaya diri dalam menjawab soal yang diberikan. 2) Sebagian besar siswa tidak dapat mengerjakan soal, terutama soal berbentuk pemecahan masalah. 3) Siswa cendrung diam dan tidak bertanya pada setiap materi yang belum dipahami.

Untuk membantu siswa dalam pembelajaran, perlu maksimal agar tujuan pembelajaran matematika dapat tercapai seperti yang diharapkan. Strategi pembelajaran yang dipilih hendaknya mampu mencapai tujuan pembelajaran matematika tersebut terutama pada aspek pemecahan masalah matematika.Salah satu solusi untuk mengatasi persoalan terebut adalah dengan menerapkan model pembelajaran kooperatif tipe Tbink Talk Write (TTW). Model pembelajaran terebut diyakini dapat membantu siswa dalam pembelajaran. Pembelajaran Kooperatif adalah model pembelajaran dengan menggunakan sistem pengelompokan/tim kecil, yaitu antara empat sampai enam orang yang mempunyai latar belakang kemampuan akademik, jenis kelamin, ras, atau suku yang berbeda (heterogen) (Wina Sanjaya, 2008). Sedangkan pembelajaran Kooperatif TTW adalah suatu pembelajaran dimulai dari keterlibatan siswa dalam berpikir atau berdialog dengan dirinya sendiri setelah proses membaca masalah, selanjutnya berbicara dan membagi ide dengan teman sebelum menuliskan permasalahannya.

Sebagai seorang guru, seharusnya mengetahui kemampuan awal siswa terlebih dahulu sebelum melakukan proses belajar mengajar. Hal ini diperlukan karena dengan mengetahui kemampuan awal siswa guru dapat menentukan strategi atau model pembelajaran yang tepat untuk diterapkan dalam pembelajaran.

Berdasarkan penelitian yang dilakukan oleh salah satu peneliti ditemukan bahwa terdapat pengaruh kemampuan awal siswa terhadap pemecahan masalah matematis siswa (Sri Adi Widodo, 2016). Berdasarkan permasalahan yang telah diuraikan, maka penulis tertarik untuk meneliti masalah tersebut dalam suatu penelitian yang berjudul "Pengaruh Penerapan Pembelajaran Kooperatif Tipe Think Talk Write (T'TW) Terhadap Kemampuan Pemecahan Masalah Matematika Ditinjau Dari Kemampuan Awal Matematika" 
Berdasarkan rumusan masalah, maka tujuan pada penelitian ini adalah untuk mendeskripsikan: 1) Ada atau tidaknya perbedaan kemampuan pemecahan masalah matematika siswa yang belajar menggunakan model pembelajaran kooperatif tipe TTW dengan siswa yang belajar menggunakan pembelajaran langsung, 2) Ada atau tidaknya perbedaan kemampuan pemecahan masalah matematika antara siswa yang belajar menggunakan model pembelajaran kooperatif tipe TTW dengan siswa yang belajar menggunakan pembelajaran langsung jika ditinjau dari kemampuan awal siswa, dan 3) Ada atau tidaknya pengaruh interaksi model pembelajaran tipe TTW yang ditinjau dari kemampuan awal terhadap kemampuan pemecahan masalah matematika siswa.

\section{TINJAUAN LITERATUR}

\section{Kemampuan Pemecahan Masalah}

Menurut Wina Sanjaya, pemecahan masalah dapat diartikan sebagai rangkaian aktivitas pembelajaran yang menekankan kepada proses penyelesaian masalah yang dihadapi secara ilmiah (Wina Sanjaya, 2008). Menurut Akbar Sutawidjaja, pemecahan masalah adalah mengorganisasikan konsep dan keterampilan kedalam pola aplikasi baru untuk mencapai tujuan(Akbar Sutawidjaja, et.al, 1991). Jadi, apabila seorang siswa dilatih untuk menyelesaikan masalah siswa itu mampu mengambil keputusan sebab siswa itu menjadi mempunyai keterampilan tentang untuk mengumpulkan informasi yang relevan, menganalisis informasi dan menyadari betapa perlunya meneliti kembali hasil yang telah diperoleh.

Kemampuan pemecahan masalah matematika siswa dapat dilihat dari indikator berikut: 1) Memahami masalah, yaitu menentukan (mengidentifikasi) apa yang diketahui, apa yang dinyatakan, syarat-syarat apa yang diperlukan, apa syarat yang bisa dipenuhi, memeriksa apakah syarat-syarat yang diketahui, dan menyatakan kembali masalah asli dalam bentuk yang lebih operasional (dapat dipecahkan), 2) Merencanakan penyelesaian, memeriksa apakah sudah pernah melihat sebelumnya atau melihat masalah yang yang sama dalam bentuk yang berbeda, memeriksa apakah sudah mengetahui soal lain yang terkait, mengaitkan dengan teorema yang mungkin berguna, memperhatikan yang tidak diketahui dari soal dan mencoba memikirkan soal yang sudah dikenal yang mempunyai unsur yang tidak diketahui yang sama, 3) Melaksanakan penyelesaian, yaitu melaksanakan rencana penyelesaian, mengecek kebenaran setiap langkah dan membuktikan bahwa langkah benar, dan 4) Memeriksa kembali, yaitu meneliti kembali hasil yang telah dicapai, mengecek hasilnya, mengecek argumennya, mencari hasil itu dengan cara lain, dan menggunakan hasil atau metode yang ditemukan untuk menyelesaikan masalah lain (Efandi Zakaria, 2007).

\section{Pembelajaran Kooperatif tipe Think Talk Write (TTW)}

Pembelajaran tipe TTW adalah model yang memfasilitasi latihan berbahasa secara lisan dan menulis bahasa tersebut dengan lancar. Model yang diperkenalkan oleh Huinker dan Laughlin ini didasarkan pada pemahaman bahwa belajar adalah sebuah prilaku sosial. Model TTW mendorong siswa untuk berfikir, berbicara dan kemudian menuliskan suatu topik tertentu. Model ini membantu siswa dalam mengumpulkan dan mengembangkan ide-ide melalui percakapan yang terstruktur. karakteristik dari model TTW ini adalah dimulai dengan berfikir melalui bahan bacaan atau masalah yang disajikan, kemudian hasil bacaan atau masalah yang disajikan dikomunikasikan dengan diskusi dan kemudian membuat laporan hasil presentasi (Istarani, 2014). Langkah-langkah pembelajaran dengan model TTW adalah sebagai berikut. (Martimis, 2008)

1) Guru memabagi lembar kerja siswa (LKS) yang memuat situasi masalah dan petunjuk serta prosedur pelaksanaannya.

2) Siswa membaca teks dan membuat catatan dari hasil bacaan secara individual, untuk dibawa keforum diskusi (Think)

3) Siswa berinteraksi dan berkolaborasi untuk membahas isi catatan (Talk). Guru berperan sebagai mediator lingkungan belajar. 


\section{4) Siswa mengonsrtuksi sendiri pengetahuan sebagai hasil kolaborasi (Write).}

\section{Kemampuan Awal Matematika}

Kemampuan awal matematika yaitu kemampuan kognitif yang telah dimiliki siswa sebelum siswa tersebut mengikuti pelajaran matematika yang nantinya akan dipelajari dan termasuk prasyarat bagi siswa tersebut dalam mempelajari pelajaran lanjutan (Farida Hanun, 2010).

\section{METODE}

Penelitian ini dilaksanakan di MTs Negeri Danau Bingkuang pada semester ganjil tahun ajaran 2017/2018. Populasi dalam penelitian ini adalah Madrasah Tsanawiyah Negeri Danau Bingkuang. Untuk Sampel dalam penelitian ini adalah kelas VII MTs Negeri Danau Bingkuang. Kelas VII.1 sebagai kelas eksperimen dan kelas VII.2 sebagai kelas kontrol dengan masing-masing jumlah siswa adalah 34 orang. Kedua kelas tersebut telah diuji homogenitasnya. Pengambilan sampel dilakukan dengan teknik Purposive Sampling.

Desain penelitian menggunakan Posttest Only Control Design (Endang Mulyantiningsih, 2011). Secara rinci desain Posttest Only Control Design dapat dilihat pada Tabel 1:

Tabel 1. Posttest Only Control Design

\begin{tabular}{ccc}
\hline Kelas & Perlakuan & Posttest \\
\hline Eksperimen & $\mathrm{X}$ & $\mathrm{O}_{1}$ \\
Kontrol & - & $\mathrm{O}_{2}$ \\
\hline
\end{tabular}

Sumber: Endang Mulyantiningsih, model penelitian Terapan Bidang Pendidikan

Instrumen yang digunakan dalam penelitian ini adalah tes. Ada dua jenis tes yang dilakukan dalam penelitian ini yaitu tes kemampuan awal, dan posttest.Tes kemampuan awaldibuat untuk mengetahui kriteria kesetaraan. Siswa diberi tes kemampuan awal untuk materi yang sudah dipelajari siswa. Postest kemampuan pemecahan masalah matematika siswa disusun dalam bentuk tes uraian. Postest kemampuan pemecahan masalah matematika siswa yaitu tes yang diberikan setelah semua materi diajarkan kepada siswa, untuk mengukur kemampuan pemecahan masalah matematika siswa pada kelas eksperimen dan kelas kontrol.

Teknik analisis data yang digunakan dalam penelitian ini adalah tes t dan ANOVA dua arah (two way $A N O V A$ ). ANOVA dua arah (two way $A N O V A$ ) digunakan bila dalam analisis data ingin mengetahui ada atau tidak perbedaan dari dua variabel bebas, sedangkan masing-masing variabel bebasnya dibagi dalam beberapa kelompok (Hartono, 2014). Sebelum melakukan analisis data dengan tes " $t$ " maka harus dilakukan yaitu: 1) uji normalitas, dan 2) uji homogenitas. Sesuai dengan rumus masalah penelitian, maka teknik yang digunakan dalam menganalisis data untuk menguji hipotesis 1 dan 2 menggunakan uji t jika datanya berdistribusi normal dan homogen, jika tidak homogen maka dengan uji t'. kemudian untuk hipotesis ke 3 menggunakan ANOVA 2 arah.

\section{HASIL DAN PEMBAHASAN}

Berdasarkan pelaksanaan model pembelajaran TTW oleh peneliti di kelas eksperimen adalah 92,36 $\%$. Sedangkan rata-rata aktivitas siswa dalam pembelajaran menggunakan model pembelajaran T'TW di kelas eksperimen adalah 88,19\%.

Tidak ada cara yang terbaik dalam pembelajaran ataupun cara belajar. Pencapaian kemampuan siswa dari suatu pendekatan pembelajaran berbeda satu sama lain. Selain dikarenakan cara penyampaian yang berbeda, juga dikarenakan karakteristik dan penekanan yang berbeda pula dari tiap-tiap pendekatan pembelajaran. Jadi, kemampuan pemecahan masalah hanya salah satu dari kemampuan dasar matematika sehingga hasil yang diperoleh dalam kemampuan pemecahan 
masalah matematika tidak cukup untuk menggeneralisasikan pada prestasi matematika secara keseluruhan.

Untuk melihat apakah terdapat perbedaan kemampuan pemecahan masalah matematika antara siswa yang menggunakan pembelajaran kooperatif dengan Model TTWdan siswa yang menggunakan pembelajaran langsung dilakukan analisis menggunakan test-t.

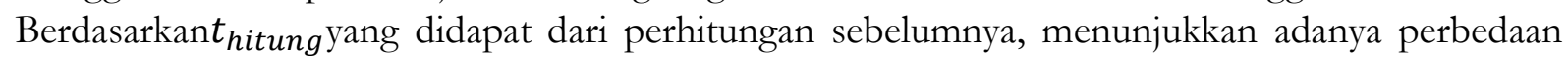
kemampuan pemecahan masalah matematika siswa antara siswa yang menggunakan pembelajaran menggunakan model TTW dengan siswa yang menggunakan pembelajaran langsung.Dengan thitung $=3,418$ dan $t_{\text {tabel }}=1,997$, berarti besar $t_{\text {hitung }}$ dibandingkan $t_{\text {tabel }}$ pada taraf signifikan $5 \%$ adalah 3,418 $>1,997$ atau $t_{\text {hitung }}>t_{\text {tabel }}$, maka $\mathrm{H}_{\mathrm{a}}$ diterima dan $\mathrm{H}_{\mathrm{o}}$ ditolak. Maka, dapat disimpulkan bahwa terdapat perbedaan kemampuan pemecahan masalah matematika siswa kelas VII MTs N Danau Bingkuang antara siswa yang diterapkan model TTW dan siswa yang diterapkan model pembelajaran langsung.

Selain itu, dari perhitungan mean nilai postest yang diberikan pada kelas eksperimen dan kelas kontrol, didapat bahwa mean dari kelas eksperimen sebesar 83,29 sedangkan mean dari siswa yang diperoleh dari kelas kontrol adalah 76,17. Jika dibandingkan, terlihat bahwa model TTW lebih baik dari pada pembelajaran langsung. Ini berarti ada pengaruh positif dari penerapan model pembelajaran kooperatif tipe TTW, dan juga model pembelajaran ini bisa menghubungkan pelajaran dengan pengalaman siswa atau dengan hal-hal lain yang memungkinkan siswa dapat menangkap keterkaitannya dalam struktur pengetahuan yang telah dimilikimya. Dengan demikian hasil analisis ini mendukung rumusan masalah yang diajukan yaitu terdapat perbedaan kemampuan pemecahan masalah matematika siswa yang menggunakan model pembelajaran TTW dengan siswa yang memperoleh pembelajaran langsung.

Untuk melihat adanya pebedaan kemampuan pemecahan masalah matematika antara siswa yang belajar menggunakan model pembelajaran kooperatif tipe T'TW dengan siswa yang belajar menggunakan pembelajaran langsung jika ditinjau dari kemampuan awal siswa. dianalisis menggunakan Anova dua arah. Sehingga diperoleh diperoleh dari nilai signifikan untuk strategi pembelajaran adalah $\mathrm{F}_{\text {hitung }}=11,488$ dan $\mathrm{F}_{\text {tabel }}=3,996$ dan nilai signifikan untuk kemampuan awal diperoleh $\mathrm{F}_{\text {hitung }}=24,316$ dan $\mathrm{F}_{\text {tabel }}=3,145$. maka terlihat $\mathrm{F}_{\text {hitung }}<\mathrm{F}_{\text {tabel. }}$. Ini berarti hipotesi alternatif (Ha) diterima dan hipotesis nihil (Ho) ditolak. Makadapat disimpulkan bahwa faktor model pembelajaran memberikan pengaruh yang signifikan terhadap kemampuan pemecahan masalah dan faktor kemampuan awal memberikan pengaruh yang signifikan terhadap kemampuan pemecahan masalah.Sesuai dengan rumusan masalah penelitian, maka teknik yang digunakan dalam menganalisis data untuk menguji hipotesis 1 dan 2, menggunakan uji t jika datanya berdistribusi normal dan homogennya dan t' jika tidak homogen. Sedangkan jika tidak berdistribusi normal, pengujiannya hipotesis langsung dengan uji nonparametric yaitu Mann Whitney U.

Tujuan dari uji ini adalah untuk mengetahui apakah komunikasi matematis siswa kelas eksperimen lebih baik dari rata-rata hasil komunikasi matematis kelas kontrol. Uji yang dilakukan dengan kriteria jika nilai signifikan yang diperoleh lebih kecil dari 0,05 maka $\mathrm{H}_{\mathrm{a}}$ diterima, jika nilai signifikan yang diperoleh lebih besar dari 0,05 maka $\mathrm{H}_{0}$ diterima. Untuk hipotesis ke 3 menggunakan uji anova dua arah.

1. Terdapat perbedaan kemampuan pemecahan masalah matematika antara siswa yang mengikuti model pembelajaran kooperatif tipe TTW dengan siswa yang mengikuti pembelajaran langsung. Hal ini dapat dilihat dari nilai $t_{\text {hitung }} 3,418$ dan $t_{\text {tabel }} 1,997$ pada taraf signifikan 5\%. maka nilai thitung $\geq$ tabel yang berarti $\mathrm{H}_{\mathrm{a}}$ diterima dan $\mathrm{H}_{0}$ ditolak.

2. Terdapat perbedaan kemampuan pemecahan masalah matematika antara siswa yang mengikuti model pembelajaran kooperatif tipe TTW dengan siswa yang mengikuti pembelajaran langsung jika ditinjau dari kemampuan awal siswa. Hal ini dapat dilihat dari nilai signifikan kemampuan pemecahan masalah $\mathrm{F}_{\text {hitung }}=11,488$ dan $\mathrm{F}_{\text {tabel }}=3,996$ dan nilai signifikan untuk kemampuan awal $\mathrm{F}_{\text {hitung }}=24,316$ dan $\mathrm{F}_{\text {tabel }}=3,145$. maka terlihat $\mathrm{F}_{\text {hitung }}<$ $\mathrm{F}_{\text {tabel }}$ yang berarti $\mathrm{H}_{\mathrm{a}}$ diterima dan $\mathrm{H}_{0}$ ditolak. 
3. Tidak terdapat pengaruh interaksi antara model pembelajaran kooperatif tipe T'TW ditinjau dari kemampuan awal siswa terhadap kemampuan pemecahan masalah matematika. Hasil dari perhitungan uji Anova dua arah diperoleh $\mathrm{F}_{\text {hitung }}=0,613 \mathrm{H}_{\mathrm{a}}$ ditolak dan $\mathrm{H}_{0}$ diterima.

Berdasarkan hasil tersebut dapat menjawab dari judul yang diangkat oleh peneliti yaitu pengaruh penerapan pembelajaran kooperatif tipe think talk write (TTW) terhadap kemampuan pemecahan masalah matematika ditinjau dari kemampuan awal siswa mts di kampar.

\section{PENUTUP}

\section{Kesimpulan}

1. Terdapat perbedaan kemampuan pemecahan masalah matematika antara siswa yang mengikuti model pembelajaran kooperatif tipe TTW dengan siswa yang mengikuti pembelajaran langsung. Hal ini dapat dilihat dari nilai thitung 3,418 dan $t_{\text {tabel }} 1,997$ pada taraf signifikan $5 \%$. maka nilai $t_{\text {hitung }} \geq t_{\text {tabel }}$ yang berarti $\mathrm{H}_{\mathrm{a}}$ diterima dan $\mathrm{H}_{0}$ ditolak.

2. Terdapat perbedaan kemampuan pemecahan masalah matematika antara siswa yang mengikuti model pembelajaran kooperatif tipe T'TW dengan siswa yang mengikuti pembelajaran langsung jika ditinjau dari kemampuan awal siswa. Hal ini dapat dilihat dari nilai signifikan kemampuan pemecahan masalah $\mathrm{F}_{\text {hitung }}=11,488$ dan $\mathrm{F}_{\text {tabel }}=3,996$ dan nilai signifikan untuk kemampuan awal $\mathrm{F}_{\text {hitung }}=24,316$ dan $\mathrm{F}_{\text {tabel }}=3,145$. maka terlihat $\mathrm{F}_{\text {hitung }}<\mathrm{F}_{\text {tabel }}$ yang berarti $\mathrm{H}_{\mathrm{a}}$ diterima dan $\mathrm{H}_{0}$ ditolak.

3. Tidak terdapat pengaruh interaksi antara model pembelajaran kooperatif tipe TTW ditinjau dari kemampuan awal siswa terhadap kemampuan pemecahan masalah matematika. Hasil dari perhitungan uji Anova dua arah diperoleh $\mathrm{F}_{\text {hitung }}=0,613 \mathrm{H}_{\mathrm{a}}$ ditolak dan $\mathrm{H}_{0}$ diterima.

Berdasarkan hasil tersebut dapat menjawab dari judul yang diangkat oleh peneliti yaitu Pengaruh Penerapan Pembelajaran Kooperatif'Tipe ThinkTalk. Write (T'TW)Terhadap Kemampuan Pemecahan Masalah Matematika Ditinjau dari Kemampuan Awal siswa MTs di Kampar.

\section{Saran}

Berdasarkan hasil penelitian ini, peneliti memberikan saran :

1. Model pembelajaran kooperatif tipe TTW dapat dijadikan salah satu alternatif strategi pembelajaran pada mata pelajaran matematika.

2. Dalam menerapkan model pembelajaran kooperatif tipe TTW ini, masih ada siswa yang kurang aktif dalam melaksanakan diskusi. Diharapkan kepada guru agar bisa mengontrol siswa secara maksimal pada saat diskusi berlangsung.

3. Penelitian ini hanya difokuskan pada kemampuan pemecahan masalah matematika siswa, peneliti menyarankan untuk peneliti yang lain agar dapat meneliti terhadap kemampuan lain dari siswa.

Dikarenakan penelitian ini hanya diterapkan pada materi operasi bentuk aljabar, diharapkan untuk penelitian serupa dapat melakukan pada meteri matematika yang lain.

\section{REFERENSI}

Arikunto Suharsimi. 2010. Prosedur Penelitian Suatu Pendekatan Praktik. Jakarta: Rineka Cipta.

Chandra Sri Rahma, dkk. Pengaruh Model Pembelajaran Kooperatif Tipe Think Talk Write dan Gender Terhadap Kemampuan Komunikasi Matematis Siswa Kelas VIII SMPN 12 Padang.Jurnal Pendidikan Matematika. 3 (1). UNP. 
Erman Suherman, dan Putra Wina, Udin S. 1999. Strategi Belajar Matematika, Jakarta, Universitas Terbuka.

Hanun Farida. Pengrub Metode Pembelajaran Dan Kemampuan Awal Terbadap Hasil Belajar Matematika. MAN 3 jakarta.

Hartono. 2014. SPSS 16.0 Analisis Data Statistik dan Penelitian. Yogyakarta: Pustaka Belajar.

Hendriana Heris \& Soemarmo Utari. 2014. Penilaian Pembelajaran Matematika. Bandung: Refika Aditama.

Huda Mifthul. 2015. Model-Model Pengajaran Dan Pembelajaran. Yogyakarta: Pustaka Pelajar.

Istarani. 2014. 50 Tipe Pembelajaran Kooperatif. Medan: CV Medan Persada.

Majid Abdul. 2014. Model Pembelajaran. Bandung: Remaja Rosdakarya.

Martinis Yamin dan Bansu I. Ansari, Taktik Mengembangkan Kemampuan Individual Siswa, (Ciputat: Referensi. 2008)

Mulyantiningsih Endang. 2011. Model Penelitian Terapan Bidang Pendidikan. Yogyakarta: Alfabeta.

Purwanto Budi, Tesis Magister, "Eksperimentasi Model Pembelajaran Kooperatif Tipe Tbin-Talk-Write (TTW) dan Tipe Think-Pair-Share (TPS) Pada Materi Statistika Ditinjau dari Kemandirian Siswa SMA di Kabupaten Madium”, (Surakarta: Universitas Sebelas Maret, 2012)

Putri Neka Amelia, dkk. Pengaruh Penerapan Model Pembelajaran Kooperatif Tipe Think Talk Write Terhadap Kemampuan Pemecahan Masalah Matematika Siswa Kelas XI IPA di SMA Negeri 1 Pariaman.Jurnal Pendidikan Matematika. 3 (3). UNP.

Putri Rizki Herlina Wati, Eksperimen Pembelajaran Matematika Dengan Strategi Team Assisted Individualization Dan Quiz Team Ditinjau Dari Kemampuan Pemecahan Masalah Siswa Kelas VIII Di Smp Muhammadiyah 8 Surakarta, dalam publikasi ilmiab Program Studi Pendidikan Matematika Universitas Mubammadiyah Surakarta. hal.1-2

Sanjaya Wina. 2008. Model Pembelajaran Berorientasi Standar Proses Pendidikan. Jakarta: Kencana.

Saryantono, Meningkatkan Pemecahan Masalah Matematika Siswa Kelas X SMA Adiguna Bandar Lampung Melalui Model Pembelajaran Investigasi Kelompok, Prosiding Semirata FMIFA Universitas Lampung, 2013. h.5

Suherman, E. dkk, 2003. Strategi Pembelajaran Matematika Kontemporer. Bandung: JICA-IMSTEP.

Suraji. 2018. Analisis Kemampuan Pemahaman konsep matematis dan kemampuan pemecahan masalah matematis siswa SMP pada Materi Sistem Persamaan Linier Dua Variabel (SPLDV), Suska Journal of Mathematics Education. 4(1), hal. 9-16.

Sutawidjaja Akbar dkk. 1991. Pendidikan Matematika. Jakarta: Depdikbud. 
Widodo Sri Adi. 2016. Pengaruh Media Komik Terhadap Kemampuan Pemecahan Masalah dan Prestasi Belajar Matematika Ditinjau dari Kemampuan Awal Siswa Kelas VIII, Jurnal Pendidikan Matematika. 2 (1).

Zakaria Efandi. 2007. Trend Pengajaran dan Pembelajaran Matematik, Kuala Lumpur: Tmn. Sg. Besi Idustri Park. 